\title{
The Affect of COPD on Pregnancy
}

Hanumantha Rao $\mathrm{P}^{1}$ and Sarvani Palaparthi $\mathbf{2}^{\star}$

${ }^{1}$ Gynecologist and Diabetologist, Sri Venkateswara Nursing Home, Guntur, Andhra Pradesh, India

${ }^{2}$ Department of Biotechnology, Acharya Nagarjuna University, Guntur, Andhra Pradesh, India

*Corresponding author: Sarvani Palaparthi, Department of Biotechnology, Acharya Nagarjuna University, Guntur, Andhra Pradesh, India, Tel: +91 9885610011; E-mail: palaparthi.sarvani@gmail.com

Received date: Nov 27, 2017; Accepted date: Nov 28, 2017; Published date: Nov 30, 2017

Copyright: (c) 2017 Rao HP, et al. This is an open-access article distributed under the terms of the Creative Commons Attribution License, which permits unrestricted use, distribution, and reproduction in any medium, provided the original author and source are credited.

Citation: Rao HP, Palaparthi S (2017) The Affect of COPD on Pregnancy. Lung Dis Treat 3: e110. doi:10.4172/2472-1018.1000e110

\section{Chronic Obstructive Pulmonary Disease}

Chronic Obstructive Pulmonary Disease is group of diseases in which emphysema and chronic bronchitis are most common.

\section{Emphysema}

Emphysema is the condition in which it interferes with outward air flow and slowly destroys air sacs in your lungs.

\section{Bronchitis}

Bronchitis causes due to mucus to build up leading to inflammation and narrowing of the bronchial tubes.

\section{Symptoms}

Symptoms vary in different stages and are briefly explained below

\section{Early stage}

1. Breathe will become difficult after mild exercise

2. Wheezing, or noisy breathing

3. Chest tightness

4. Chronic cough, with or without mucus

5. Frequent colds, flu, or other respiratory infections

6. Lack of energy

\section{Second stage}

1. Fatigue

2. Swelling of the feet, ankles, or legs

3. Weight loss

4. Symptoms which needs to hospitalised are

5. Trouble in breathing or unable to talk because of low supply of air

6. Confused, muddled, or faint because of low $\mathrm{O}_{2}$ supply

7. In case of higher heart beat bluish or gray fingernails or lips, as this indicates low oxygen levels in your blood

\section{COPD Affect on Pregnancy}

Chronic obstructive pulmonary disease is a condition in which the disease worsens over time and it makes it difficult even to breathe and it is mostly caused due to smoking.
It is of 2 forms and some people will have the combination of both.Bronchitis is very dangerous condition in pregnancy which causes fatigue and energy will be diverted away from the growing foetus.

Pregnancy can also make you feel short of breath, but it's generally a good idea to try to move your body whenever possible.

Cardiorespiratory system is affected during pregnancy because of the anatomic and physiologic variations changes occur in body. Because of the increased mucous secretion the upper airway becomes hyper emic, leading to nasal obstruction, and occasionally epistaxis. During the third trimester changes may occur in patients with preexisting disease.

The volume of blood will increase from $6^{\text {th }}$ week to $40^{\text {th }}$ week of pregnancy to $40 \%$ than normal and in this condition the red blood cells remains same but there will be raise in the plasma level which results in hemo-dilution, anaemia and decrease in serum protein level.

The Cardiovascular changes are increased heart rate and stroke volume. The stroke volume increase in $10^{\text {th }}$ week and peaks at 20 to 24 weeks. From 5 to 12 weeks there will be increase in heart rate and reaches a maximum at 32 weeks which causes rise in Blood pressure during pregnancy and remains below pre-pregnancy levels. During pregnancy the Central venous pressure, pulmonary artery pressure, and pulmonary capillary wedge pressure will not change [1-7].

\section{References}

1. Fishburne JI (1979) Physiology and disease of the respiratory system in pregnancy. J Reprod Med 22: 177.

2. Ueland K (1976) Maternal cardiovascular dynamics: VII. Intrapartum blood volume changes. Am J Obstet Gynecol 126: 671.

3. Zeldis SM (1992) Dyspnea during pregnancy: Distinguishing cardiac from pulmonary causes. Clin Chest Med 13: 567.

4. Elkus R, Popovich J (1992) Respiratory physiology in pregnancy. Clin Chest Med 13: 555.

5. Hughes CW, Popovich J Jr. (1990) Pinpointing the cause of respiratory crises in pregnancy. J Crit Illness 5: 559.

6. Ratigan TR (1983) Anatomic and physiologic changes of pregnancy: Anesthetic considerations. J Am Assoc Nurse Anesth 51: 38.

7. Palaparthi S (2017) Role of Homeostasis in Human Physiology: A Review. J Med Physiol Ther 1: 101. 